\title{
Hermeneutika Alkitab Dalam Sejarah: Prinsip Penafsiran Alkitab Dari Masa ke Masa
}

\author{
Yohanes Verdianto \\ Universitas Halmahera \\ verdianto777@gmail.com
}

\begin{abstract}
The practice of hermeneutics has become an inseparable part of human history. Hermeneutics as human activity arises from the need to interpret thoughts or texts written by others. $A$ historical search reveals that there have been some changes in the principles of biblical hermeneutics. This paper aims to find out what are the principles of hermeneutics that developed from the early church up to the postmodern era. This paper is a historical approach using documentary research method. The results of this study state that there are at least three principles of biblical interpretation from the early church to postmodern times. First, the literal hermeneutics of the Bible was agreed upon by all early church Fathers, although contextual, grammatical, and historical interpretation of the Bible was emphasized by two church Fathers, namely Theodore and Chrysostom. This literal hermeneutics was used until the reform era. Second, modern hermeneutics refers to reason rather than the literal principle. This is the emerge of hermeneutics of relativism which bases truth on the senses and reasons. This principle agrees the application of rationalism to the Bible which leads to historicalcritical. Third, contemporary (postmodern) hermeneutics is more towards a process of understanding that is temporary. This means that understanding has no clear boundaries, and that interpreters cannot reach a fully certain understanding. Thus, contemporary biblical hermeneutics is full of subjectivism, relativism, pluralism and is temporary.
\end{abstract}

Keywords: hermeneutic, bible, postmodern, literal, relativism.

\begin{abstract}
Abstrak: Praktik hermeneutika telah menjadi bagian tak terpisahkan dari sejarah manusia. Hermeneutika sebagai aktivitas manusia muncul dari kebutuhan untuk menafsirkan pemikiran atau teks yang ditulis oleh orang lain. Penelusuran sejarah menyatakan bahwa terjadi beberapa perubahan dalam prinsip hermeneutika Alkitab. Tulisan ini bertujuan untuk mencari tahu apa saja prinsip-prinsip hermeneutika yang berkembang sejak gereja mula-mula sampai ke zaman postmodern saat ini. Tulisan ini menggunakan sebuah pendekatan sejarah dengan menggunakan metode penelitian dokumen. Hasil dari penelitian ini menyatakan bahwa setidaknya ada tigaprinsip penafsiran Alkitab sejak gereja mula-mula sampai ke zaman postmodern. Pertama, hermeneutika Alkitab secara literal yang disetujui oleh semua bapa-bapa gereja mula-mula, meskipun penafsiran Alkitab secara kontekstual, gramatikal, dan historis ditekankan oleh dua bapa gereja, yaitu Theodore dan Chrysostom. Hermeneutika literal ini digunakan sampai era reformasi. Kedua, hermeneutika modern yang lebih mengarah kepada alasan daripada prinsip literal. Hal ini memunculkan hermeneutika relativisme yang mendasarkan kebenaran pada indera dan alasan.Prinsip ini menyepakati penerapan rasionalisme pada Alkitab yang mengarah pada historis-kritis. Ketiga, hermeneutika kontemporer (postmodern) lebih ke arah sebuah proses pemahaman yang bersifat sementara (tidak kekal). Ini berarti bahwa pemahaman tidak memiliki batasan yang tegas, dan bahwa interpreter tidak dapat mencapai pemahaman yang sepenuhnya pasti. Dengan demikian, hermeneutika Alkitab kontemporer penuh dengan subjektivisme, relativisme, pluralisme dan bersifat sementara.
\end{abstract}

Kata Kunci: hermeneutika, alkitab, postmodern, literal, relativisme.

\section{PENDAHULUAN}


Praktik hermeneutika telah menjadi bagian tak terpisahkan dari sejarah manusia. Hermeneutika sebagai aktivitas manusia muncul dari kebutuhan untuk menafsirkan pemikiran atau teks yang ditulis oleh orang lain. Meskipun sepanjang sejarah kata hermeneutika telah didefinisikan dalam banyak cara, namun kata ini sendiri berasal dari kata Yunani hermenuein yang berarti "menafsirkan," yang berasal dari kata dewa Yunani Hermes. Hermes dianggap sebagai utusan dari juru kabar yang menerjemahkan atau menafsirkan pesan-pesan dari para dewa kepada manusia ("Hermeneutic," 1990).

Dalam tindakan penyampaian atau penafsiran ini, setidaknya terdapat dua komponen mendasar. Pertama, tidak mungkin untuk menyampaikan atau menafsirkan pemikiran atau teks apa pun tanpa konsepsi yang benar tentang pemikiran atau teks tersebut. Dengan demikian komponen penting pertama dari hermeneutika adalah konsepsi. Kedua, sebuah pemikiran atau teks tidak sepenuhnya disampaikan sampai apa yang telah dipahami dengan benar telah diwakili dengan benar. Dengan demikian, komponen penting kedua dari hermeneutika adalah representasi, yang umumnya dipahami sebagai interpretasi, yaitu untuk memberikan konsepsi sendiri tentang sesuatu (Maier, 1994). Interpretasi diperlukan untuk menjadikan makna sebuah pemikiran atau teks menjadi transparan, terang, jelas, dan gamblang (Ampel, 2007).

Tulisan ini bertujuan untuk menguraikan prinsip-prinsip umum hermeneutika yang diterapkan pada Alkitab. Pembahasan akan dimulai dengan menelusuri sejarah hermeneutika Alkitab sejak gereja mula-mula sampai ke zaman kontemporer sekarang ini.

\section{METODE PENELITIAN}

Tulisan ini menggunakan sebuah pendekatan sejarah dengan menggunakan metode penelitian dokumen. Penelitian ini menggunakan pendekatan kualitatif dengan metode deskripsi analitis, yaitu berusaha menguraikan berkenaan dengan hermeneutik dalam sejarah, yaitu sejarah hermeneutik masa lalu sampai masa kini. 


\section{HASIL DAN PEMBAHASAN}

\section{Hermeneutika Masa Lampau}

Bagian ini akan membahas tentang pengertian dan praktik hermeneutika Alkitab dari gereja mula-mula hingga zaman reformasi.

Gereja Mula-mula. Permulaan hermeneutika Kristen Alkitabiah berasal dari abad pertama. Diakui bahwa umat Kristen awal tidak hanya membagikan Kitab Suci orang Yahudi, yaitu Perjanjian Lama, tetapi juga metode-metode penafsirannya (Dockery, 1992). David Dockery mengidentifikasi empat pendekatan utama Yahudi terhadap penafsiran Alkitab, yaitu: literal, midrash, pesher, dan tipologi (Dockery, 1992). Dalam bukunya ini, Dockery mengatakan bahwa pendekatan literal dianggap sebagai dasar bagi semua pendekatan lainnya karena didasarkan pada pemahaman yang jelas dan literal dari teks Alkitab. Sedangkan pesher melihat teks Alkitab dari perspektif apokaliptik. Akhirnya, pendekatan tipologis berusaha menemukan korespondensi antara orang-orang dan peristiwa dari masa lalu dan masa kini atau masa depan.

Sementara orang-orang percaya mula-mula mengadopsi beberapa pendekatan ini, mereka juga mengandaikan sebuah hermeneutika Kristologi yang mendasar, yang berarti bahwa peristiwa-peristiwa yang dialami dalam kehidupan Kristus memberikan lensa atau kerangka dasar yang melaluinya Perjanjian Lama dipandang.

Yang penting bagi pendekatan-pendekatan di atas untuk penafsiran Alkitab adalah keyakinan yang kuat akan inspirasi llahi terhadap Kitab Suci, dan keyakinan bahwa karena Taurat memuat seluruh kebenaran Allah untuk tuntunan umat manusia, maka tujuan dari semua penafsiran adalah untuk menerjemahkan kata-kata Allah tersebut ke dalam kehidupan manusia (Dockery, 1992).

Abad kedua dan seterusnya melihat tantangan yang mengarah pada perkembangan baru dalam penafsiran Alkitab. Secara umum, Alkitab terus dipandangasal usulnya berasal dari Allah, dan bahwa tujuan Ilahi ada di balik setiap perikopnya. Demikian pula halnya dengan pendekatan yang kontras dari aliran Aleksandria dan Antiokhia. Aliran Aleksandria menekankan pendekatan alegoris, 
sementara aliran Antiokhia mengadopsi pendekatan yang lebih literal dan historis. Ringkasan Dockery sangat membantu dalam memberikan gambaran sehubungan dengan penafsiran Alkitab oleh gereja mula-mula, "semua bapa-bapa gereja mulamula menyetujui arti literal dari Kitab Suci, tetapi interpretasi kontekstual, gramatikal, dan historis ditekankan oleh Theodore and Chrysostom, dengan konvergensi yang berkembang ke arah itu oleh Jerome, Augustine, and Theodoret" (Dockery, 1992). Dalam hal ini semua bapa-bapa gereja mula-mula menyetujui penafsiran Alkitab secara literal, meskipun penafsiran Alkitab secara kontekstual, gramatikal, dan historis ditekankan oleh dua bapa gereja, yaitu Theodore dan Chrysostom.

Hermeneutika Abad Pertengahan. John Cassian (360 - 435) memetakan jalur penafsiran yang diikuti dari Agustinus sampai periode abad pertengahan. Dia mengembangkan teori penafsiran sehubungan dengan pengertian Kitab Suci yang terdiri dari empat aspek, yaitu indera literal, alegoris, tropologis dan anagogis. Penafsiran Alkitab dimaksudkan untuk memelihara iman, harapan dan cinta, dan diakui bahwa penafsiran literal sering kali mencapai tujuannya. Namun, ketika dirasakan bahwa penafsiran literal tidak memenuhi tujuan tersebut, maka penafsiran alegoris diperlukan untuk meningkatkan iman, tropologis untuk memelihara cinta, dan anagogis untuk meningkatkan harapan (Dockery, 1992). Dalam pengertian ini, misalnya adalah kota Yerusalem yang secara umum dipahami secara literalsebagai kota Yahudi, secara alegoris sebagai gereja Kristus, secara tropologis sebagai jiwa pria dan wanita, dan secara anagogis sebagai kota surgawi (Dockery, 1992).

Hermeneutika Era Reformasi. Selama reformasi, hermeneutika melihat adanya peningkatan bertahap terhadap prioritas makna literal atas makna alegoris. Perkembangan pemahaman hermeneutika ini dikreditkan kepada Martin Luther (1483-1546), Erasmus (1466-1536) dan John Calvin 1509-1564. Secara khusus, Calvin diakui sebagai penafsir terbesar reformasi yang memberikan dorongan kepada pengembangan dan penggunaan metode eksegetis gramatikal-historikal (Dockery, 1992).

Presaposisi Hermeneutika Masa Lampau. Keyakinan mendasar dari para praktisi hermeneutika Alkitab adalah kepercayaan akan asal usul Alkitab. Karena itu, diyakini bahwa tujuan Ilahi ada di balik setiap bagian dari Alkitab. Dengan demikian, arti literal dari Kitab Suci itu sangatlah penting, yaitu, kata-kata dari Kitab Suci membawa makna tertentu yang perlu dipahami untuk menemukan tujuan Ilahi di 
balik teks Alkitab. Bahkan ketika perbedaan dibuat seperti halnya oleh Thomas Aquinas (1224-1274), yang membedakan pengertian spiritual dan literal atas dasar filsafat Aristoteles, namun ia tetap memahami pengertian literal sebagai pengertian primer (Steinmetz, 1980). Harus disebutkan bahwa, bahkan di antara bapa-bapa gereja - Theodore, Chrysostom, Jerome, Augustine, dan Theodoret - pengertian literal dari Kitab Suci tidak menghalangi mereka untuk mempertimbangkan konteksnya.

Jelaslah bahwa pandangan gereja masa lampau sehubungan dengan hermeneutika lebih ke arah makna literal dibandingkan makna alegori dan lainnya.

\section{Hermeneutika Masa Kini}

Bagian ini akan membahas tentang pengertian dan praktik hermeneutika Alkitab dari era reformasi sampai kepada saat ini.

Perkembangan budaya paling penting di dunia Barat yang berada di antara hermeneutika masa lampau dan hermeneutika masa kini adalah Pencerahan pada abad ke-18. Pencerahan relevan dengan diskusi tentang hermeneutika karena sejak awal abad Pencerahan ini, ada pencarian untuk sebuah matriks - sesuatu di dalam atau dari mana sesuatu yang lain berasal, berkembang, atau mengambil bentuk ("Matrix," n.d.), yang pasti dan permanen yang dapat digunakan untuk menentukan apa yang benar, nyata, rasional, benar, dan baik. Terutama ketika Rene Descartes pada abad Pencerahan menemukan matriks tersebut (William J. Larkin, 1988; Richard J. Bernstein, 1983). Descartes melihat matriks sebagai sebuah alat yang yang sangat berguna untuk mengeksplorasi pertanyaan-pertanyaan mendasar tentang pengetahuan dan realita (Irwin, 2002). Matriks inilah yang akan membentuk opini kita dengan informasi yang dikumpulkan melalui indera penglihatan, pendengaran, sentuhan, penciuman, dan rasa (Descartes, 1985).

Pemikiran Descartes ini membuat terjadinya peralihan pada realita kebenaran dan makna, yang ditentukan oleh "alasan-alasan" dan tidak lagi oleh "wahyu" (Larkin, 1988). Hal ini menjelaskan bahwa Pencerahan dengan hasratnya untuk sebuah objektivitas seperti ini, akhirnya memunculkan relativisme yang menjadi ciri kebuntuan hermeneutika yang kita hadapi saat ini. Singkatnya, hermeneutika relativisme terjadi karena kebenaran didasarkan pada indera dan alasan, dan tentu saja indera dan alasan setiap orang bisa berbeda-beda. 
Selain Descartes, ada beberapa tokoh lain yang membentuk hermeneutika pada abad Pencerahan. Mereka adalah Larkin yang memberikan kepada kita pemahaman sehubungan dengan "knowing self' yang dicetuskan oleh Descartes. Kemudian Immanuel Kant menjelaskan tentang sebuah perbedaan antara pengetahuan tentang nuomena (nuomenal: "Objek atau peristiwa yang muncul dengan sendirinya terlepas dari persepsi dan indera) ("noumenon," n.d.) dan fenomenal. Preunderstanding (Preunderstanding adalah istilah teknis yang digunakan dalam bahasa teologi dan filsafat untuk merujuk pada apa yang kita bawa secara tidak refleks terhadap pembacaan suatu teks) dan lingkaran hermeneutika yang dicetuskan oleh Friedrich Schleiermacher (Larkin, 1988). Yang timbul dari kombinasi kekuatan-kekuatan ini adalah pengembangan metode historis-kritis. Secara umum disepakati bahwa penerapan rasionalisme pada Alkitab adalah salah satu penyebab utama yang mengarah pada historis-kritis (Maier, 1994).

Metode Historis Kritis.Tidak cukup ruang bagi kita untuk memberikan penjelasan secara lengkap tentang metode historis-kritis, tetapi signifikansi hermeneutisnya perlu diuraikan secara singkat. Metode historis-kritis sebagaimana yang diterapkan pada Kitab Suci akan mengungkapkan apa yang sebenarnya terjadi secara objektif. Tetapi karena ini adalah sebuah metode yang berkomitmen pada Pencerahan, maka metode ini memiliki prinsip-prinsip tertentu, yaitu prinsip-prinsip kritik, analogi, dan korelasi.

Prinsip kritik yang dimaksud di sini berarti bahwa "penilaian kita tentang masa lalu tidak dapat dengan mudah diklasifikasikan sebagai benar atau salah tetapi harus dilihat sebagai sebuah klaim terhadap tingkat probabilitas yang lebih besar atau lebih kecil dan harus selalu terbuka untuk direvisi" (Hansel, 1985). Dengan kata lain, kita harus selalu memulainya dengan keraguan. Prinsip analogi, di sisi lain, mengharuskan kita melanjutkan asumsi bahwa peristiwa-peristiwa yang terjadi di masa lalu adalah sejalan dengan peristiwa-peristiwa dari pengalaman kita sendiri saat ini. Dengan kata lain, prinsip ini mengacu pada homogenitas mendasar dari semua peristiwa sejarah (Hansel, 1985).

Dengan metode historis-kritis ini maka kesimpulan yang diambil adalah bahwa realitas saat ini menentukan status kebenaran masa lalu. Karena alasan inilah mukjizat dianggap mustahil hari ini. Akhirnya prinsip korelasi masa lalu dan masa kini mengharuskan kita untuk melihat setiap peristiwa sejarah berkorelasi dengan 
peristiwa lainnya dalam seri yang sama. Macquarrie menjelaskan esensi dari prinsip ini:

Ada kesinambungan integral dalam sejarah, sehingga segala sesuatu yang terjadi harus dianggap imanen (tetap ada) dalam hubungan sebab akibat yang sangat kompleks. ... Namun, pokok dari prinsip korelasi adalah, bahwa walaupun mungkin ada peristiwa-peristiwa yang berbeda, dan bahkan peristiwa-peristiwa yang sangat berbeda, semua peristiwa-peristiwa memiliki urutan yang sama, dan dapat dijelaskan dalam hal apa yang imanen dalam sejarah itu sendiri (Macquarrie, 1988).

\section{Friedrich Schleiermacher (1768-1834): Bapak Hermeneutika Modern}

Sejauh prinsip-prinsip Pencerahan dan metode historis-kritis mengurangi kemungkinan wahyu / ilham llahi, urgensi membangun makna literal teks sudah berkurang. Schleiermacher, seorang pietis dan filsuf mistik memahami tantangan hermeneutis yang ditimbulkan oleh kritik sejarah dan berusaha untuk menekankan lokus yang berbeda untuk sebuah makna. Jadi, sementara banyak ahli yang berfokus pada metode historis-kritis, Schleiermacher menunjukkan minat pada hermeneutika baru.

Pergeseran fundamental dalam perkembangan hermeneutika adalah ketika hermeneutika sebagai metodologi pemahaman berubah menjadi filsafat. Perubahan ini dipengaruhi oleh corak berpikir masyarakat modern yang berpangkal pada semangat rasionalisasi, di mana akal menjadi patokan bagi kebenaran yang berakibat pada penolakan hal-hal yang tidak dapat dijangkau oleh akal atau metafisika. Hal ini merupakan pemikiran Friedrich Schleiermacher ketika dia mencetuskan idenya dalam hermeneutika, yaitu universal hermeneutic. Dalam gagasannya ini, teks Alkitab sepatutnya diperlakukan sebagaimana teks-teks lain yang dikarang oleh manusia (Muchtar, 2016).Hermeneutika modern ini menempatkan semua jenis teks pada posisi yang sama, tanpa memerdulikan apakah teks itu Ilahi atau tidak, dan ini adalah bagian dari upaya liberalisasi Alkitab. Bagi Schleiermacher, faktor kondisi dan motif pengarang sangatlah penting untuk memahami makna suatu teks, di samping faktor gramatikalnya (Mircea, 1990).

Dalam pengantar tulisan ini, penulis membuat pengamatan bahwa hermeneutika kontemporer menunjukkan kecenderungan untuk isu-isu mengenai konsepsi dan pemahaman. Meskipun diskusi hermeneutika pada abad ke-19 dimulai dengan pengembangan aturan untuk interpretasi yang tepat, perhatian kemudian 
bergeser ke pertanyaan yang lebih mendasar mengenai kondisi-kondisi untuk sesuatu yang lebih mungkin untuk dimengerti (Maddox, 1985). Dengan gagasan preunderstanding, Schleiermacher mulai membahas kondisi untuk kemungkinan memahami apa pun. Dia mengubah hermeneutika Alkitabiah tradisional menjadi hermeneutika umum/universal yang menggabungkan semua jenis teks. Dengan membawa penyelidikan hermeneutika ke tingkat universal, Schleiermacher membuka masalah interpretasi kepada suatu ruang lingkup pemahaman dan penjelasan yang baru (Graham, 1993).

Metode interpretasi gramatikal yang diperkenalkan oleh Schleiermacher melibatkan pemahaman teks, yang membutuhkan pemahaman kata-kata dan bahasa umum. Seseorang harus memeriksa kata-kata dalam kaitannya dengan kalimat, dan kalimat dalam konteks paragraf, dan seterusnya, hingga pemahaman teks dapat dicapai secara akurat. Ini memunculkan apa yang oleh Schleiermacher disebut sebagai "lingkaran hermeneutika." Kita tidak dapat memahami arti dari keseluruhan teks selain dari memahami makna dari kalimat individu, dan bahkan kata-kata, dalam teks tersebut. Di sisi lain, kita tidak dapat memahami bagian-bagian individual dengan benar selain memahaminya secara menyeluruh. Inilah yang dimaksud dengan lingkaran hermeneutika (Stiver, 1996).

Lebih lanjut Schleiermacher menjelaskan tentang interpretasi gramatikal dengan cara berikut,"Kosakata dan sejarah usia penulis bersama-sama membentuk keseluruhan dari mana tulisan-tulisannya harus dipahami sebagai sebuah bagian" (Schleiermacher, 1977). Schleiermacher menunjukkan bagaimana studi tentang sejarah linguistik, serta budaya dan masyarakatnya, sangat penting untuk metode penafsiran tata bahasa. Bahasa terikat oleh kehidupan orang-orang dan kepentingan komunitas, oleh karena hal itu menciptakan genre baru yang mencerminkan sejarah penulis. Dengan demikian, maka seorang interpreter harus berkenalan dengan kehidupan dan waktu penulis. Keakraban konteks biografi dan sejarah penulis adalah prasyarat untuk sebuah metode interpretasi (Schleiermacher, 1977).

\section{Rudolf Bultmann (1884-1976): Hermeneutika Eksistensial}

Pemahaman Bultmann sehubungan dengan hermeneutika banyak dipengaruhi oleh pemikiran hermeneutika eksistensial yang dikemukakan oleh Heidegger. Heidegger mengatakan bahwa jika kehidupan manusia telah menjadi pokok bahasan hermeneutika, dan kehidupan manusia secara radikal adalah 
historis, maka tak dapat dihindari bahwa kehidupan manusia itu akan menjadi subjek dari analisis yang ketat. Heidegger merupakan titik balik yang signifikan dalam pemahaman hermeneutika. Baginya, manusia hanya dapat menafsirkan dunia sebagaimana ia melihatnya dari situasi kehidupan yang diberikan (Thiselton, 1993).

Bagi hermeneutika Bultmann, Perjanjian Baru dapat ditafsirkan (dipahami) dengan tepat ketika kemungkinan eksistensial soal iman disesuaikan untuk menghasilkan pemahaman diri yang baru yang dapat dimengerti (Dockery, 1992). Sebagai contoh, ketika dalam Kisah 17:31 Alkitab mengatakan bahwa Allah telah menetapkan hari di mana la akan menghakimi dunia, menurut Bultmann ini hanyalah berarti bahwa manusia "harus memilih jalannya sendiri dalam hal tanggungjawab dan keputusan" (Bultmann, 1960).

Hermeneutika eksistensial, ketika berkembang terutama dalam karya-karya Bultmann mendapat tekanan. Poin utama keberatannya berkaitan dengan fakta bahwa dalam hermeneutika eksistensial, interpretasi pada dasarnya berorientasi pada eksistensi manusia terhadap kelalaian aspek teologis dan kognitif. Salah seorang yang keberatan dengan pandangan hermeneutika eksistensial Bultmann adalah Wolfhart Pannenburg. Dia mengatakan bahwa seharusnya biarkan teks Alkitab itu mengatakan apa yang seharusnya dikatakan oleh Alkitab itu sendiri, dan bukannya diberikan pemikiran eksistensial terhadap teks Alkitab tersebut (Pannenburg, 1967).

Tokoh hermeneutika lainnya yang akan dibahas dalam hermeneutika masa kini adalah Hans-Georg Gadamer yang ingin bergerak melampaui hermeneutika eksistensial dengan memfokuskan hermeneutika pada bahasa dan subjek.

\section{Hans-Georg Gadamer (1900-2002): Hermeneutika Pemahaman}

Gadamer mengeksplorasi penggunaan hermeneutika dalam semua disiplin ilmu kehidupan. Dia menunjukkan bagaimana metode hermeneutika sangat mendasar bagi semua pemahaman manusia. Teori Gadamer bertumpu pada tiga pengungkapan kebenaran: seni, sejarah dan bahasa. Dalam pandangan Gadamer, seni memberikan jendela yang lebih baik untuk memahami sejarah dan kenyataan, karena seni adalah bagian penting dari pemikiran (Klemm, 1986). Dalam hal ini, hermeneutika ibarat sebuah permainan, pemain tidaklah mengendalikan permainan, 
melainkan permainan yang mengendalikan pemain. Pemikiran kitalah yang mengendalikan hermeneutika, sehingga diperlukan seni untuk mengendalikannya.

Pengungkapan kedua dalam hermeneutika Gadamer adalah sejarah. Dalam hal ini Gadamer menegaskan bahwa sebuah hermeneutika tidaklah objektif jika melangkah keluar dari sejarah, karena sejarah dan tradisi mempersiapkan kita untuk mengetahui dan memahami hermeneutika. Dengan merekonstruksi kepentingan sosial, politik, agama dan ekonomi dari zaman si penulis, maka kita dapat memperoleh pemahaman yang lebih lengkap (Stiver, 1996). Ada hal-hal yang terjadi pada masa lalu yang merupakan gambaran dari apa yang terjadi sekarang, demikian juga kejadian masa sekarang adalah cerminan dari peristiwa yang terjadi di masa lalu. Sehingga penelusuran sejarah ini sangatlah diperlukan dalam sebuah hermeneutika (Klemm, 1986).

Bagian ketiga dari hermeneutika Gadamer adalah bahasa. Baginya semua pengertian berakar pada bahasa. Gadamer mengklaim bahwa pemahaman hermeneutika terjadi ketika teks dan penafsirnya saling menyatu. Seorang interpreter teks harus hati-hati memahami arti tersembunyi dari bahasa yang diungkapkan oleh si penulis. Fokus Gadamer adalah pada signifikansi filosofis dari apa yang dimaksud oleh penulis teks tersebut (Graham, 1993).

Dalam hal ini, fokus Gadamer bukan pada si penulis melainkan pada seorang interpreter teks dan bagaimana dia menyelami arti dari signifikansi filosofi yang terkandung dalam teks tersebut.Sehingga seorang interpreter teks dapat memahami pokok pembahasan, sifat bahasa yang digunakan, dan waktu penulisannya, sehingga diharapkan teks tersebut merupakan sebuah eksposisi dari sesuatu yang melebihi teks itu sendiri (Dockery, 1992). Dengan demikian, jelaslah bahwa Gadamer menolak gagasan bahwa sebuah teks, khususnya teks Alkitab adalah kepercayaan mutlak yang memiliki konten yang tetap stabil dan konstan (Dockery, 1992).Mengikuti pola Gadamer ini, maka sebuah hermeneutika era postmodern akan bervariasi tergantung dari interpreternya, sehingga bisa saja arti sebuah teks Alkitab dipertanyakan (Richardson \& Bowden, 1983).

\section{KESIMPULAN}


Tulisan ini memberikan gambaran singkat tentang sejarah hermeneutika pada masa lalu hingga masa kini. Dalam hal ini didapati bahwa hermeneutika kontemporer membuktikan adanya tiga pendekatan utama terhadap hermeneutika. Roy J. Howard menyajikan sebuah pengantar kepada berbagai teori pengertian yang berbeda saat hal itu dihubungkan dengan artinya. Adapun ketiga pendekatan utama dari hermeneutika ini adalah analisa, psikososial, dan ontologis (Howard, 1982). Hal serupa juga dikemukakan oleh Josef Bleicher yang mengindentifikasi tiga aliran pemikiran utama dalam sebuah diskusi filosofi komtemporer tentang hermeneutika yang boleh dikata sejajar dengan klasifikasi yang telah disebutkan oleh Howard (Bleicher, 1980).

Poin inti yang dapat dibuat sehubungan dengan hermeneutika kontemporer adalah tentang sebuah proses pemahaman yang bersifat sementara (tidak kekal). Ini berarti bahwa pemahaman tidak memiliki batasan yang tegas, dan bahwa penafsir tidak dapat mencapai pemahaman yang sepenuhnya pasti. Dengan demikian, penafsiran Alkitab kontemporer penuh dengan subjektivisme, relativisme, pluralisme dan bersifat sementara.

\section{DAFTAR PUSTAKA}

Ampel, P. S. I. S. (2007). Hermeneutika dan Fenomenologi Dari Teori ke Praktik. Surabaya: PPs IAIN Sunan Ampel Surabaya.

Bernstein, R. J. (1983). Beyond Objectivism and Relativism: Science, Hermeneutic, and Praxis. Philadelphia: University of Pennsylvania Press.

Bleicher, J. (1980). Contemporary Hermeneutics. London: Routeledge and Kegan Paul.

Bultmann, R. (1960). This World and Beyond: Marburg Sermons. London: Lutterworth Press.

Descartes, R. (1985). The Philosophical Writings of Descartes. ( and A. K. J. Cottingham, R. Stoothoff, D. Murdoch, Ed.). Cambridge: Cambridge University Press.

Dockery, D. S. (1992). Biblical Interpretation Then and Now: Contemporary 
Hermeneutics in the Light of the Early Church. Grand Rapids: Baker Book House.

Graham, T. (1993). The Dual Aspect of Hermeneutics. Studies in Religion, 110.

Hansel, G. F. (1985). Biblical Interpretation Today. Lincoln: College View Printers.

Hermeneutic. (1990). In The Encyclopedia of Religion (15th ed., p. s.v). Encyclopedia Britannica Inc.

Howard, R. J. (1982). Three Faces of Hermeneutics. Berkeley: University of California Press.

Irwin, W. (2002). The Matrix and Philosophy. (William Irwin, Ed.). Chicago: Open Court.

Klemm, D. E. (1986). Hermeneutical Inquiry: The Interpretation of Texts. Atlanta: Scholars Press.

Larkin, W. J. (1988). Culture and Biblical Hermeneutics. Grand Rapids: Baker Book House.

Macquarrie, J. (1988). Twentieth-Century Religious Thought. Philadelphia: Trinity Press International.

Maier, G. (1994). Biblical Hermeneutics. Wheaton: Crossway Books.

Matrix. (n.d.). Retrieved May 10, 2020, from https://www.merriamwebster.com/dictionary/matrix

Mircea, E. (1990). The Encyclopedia of Religion (15th ed.). Chicago: Encyclopedia Britannica Inc.

Muchtar, M. I. (2016). Analisis Konsep Hermeneutika Dalam Tafsir Alquran. Hunafa: Jurnal Studia Islamika, Vol. 13, N, 73.

noumenon. (n.d.). Retrieved May 10, 2020, from https://www.merriamwebster.com/dictionary/noumenon

Pannenburg, W. (1967). Hermeneutics and Universal History. (R. W. Funk, Ed.). Tubingen: Mohr. 
Randy L. Maddox. (1985). Contemporary Hermeneutic Philosophy and Theological Studies. Religious Studies, 21, 517.

Richardson, A., \& Bowden, J. (1983). The Westminster Dictionary of Christian Theology. Philadelphia: The Westminster Press.

Schleiermacher, F. (1977). Hermeneutics: The Handwritten Manuscripts. (Heinz Kimmerle, Ed.). Missoula: Scholars Press.

Steinmetz, D. C. (1980). The Superiority of Precritical Exegesis. Theology Today, 27, 31-32.

Stiver, D. R. (1996). The Philosophy of Religious Language. Oxford: Blackwell Publishers.

Thiselton, A. (1993). The Two Horizons. Grand Rapids: Eerdmans Publishing Company. 